\title{
Estucos y hormigones romanos de la ciudad de Baelo Claudia (Cádiz): Caracterización y causas de deterioro.
}

\author{
Stuccos and roman concretes of the Baelo Claudia city (Cádiz): \\ Characterization and causes of decay.
}

FRANCISCA PUERTAS, Ma TERESA BLANCO -VARELA y ÁNGEL PALOMO Instituto Eduardo Torroja - CSIC

ESPAÑA

Fecha de recepción: 17-XI-94

\begin{abstract}
RESUMEN
Se ha estudiado la naturaleza y estado de conservación de distintos estucos y hormigones romanos procedentes de la ciudad romana de Baelo Claudia (Cádiz). Se ha establecido la composición química, mineralógica y microestructural de dichos materiales. Se han encontrado diferentes causas de su deterioro. Entre ellas, cabe destacar la pérdida del material ligante (cal), fundamentalmente motivado por procesos de solubilización parcial; la falta de adherencia entre los estucos y la piedra soporte, debido a las diferentes características y propiedades de ambos materiales; $y$ finalmente, también al ataque de tipo biológico, con la proliferización y colonización de distintos organismos en dichos materiales.
\end{abstract}

\begin{abstract}
This paper presents the study of the nature and conservation state of different stuccos and Roman concretes from the Roman city of Baelo Claudia (Cádiz). The chemical, mineralogical and microstructural compositions of the said materials have been established. Different causes of their decay have been found, among which we should emphasize the loss of the binding material (ime), basically due to the processes of partial solubilization; the lack of bond between the stuccos and the support stone, due to the different characteristics and properties of these two materials; and finally, the biological-type attack with the proliferation and colonization of different organisms in the said materials.
\end{abstract}

\section{INTRODUCCIÓN}

La ciudad de Baelo Claudia, situada en el suroeste de la provincia de Cádiz, se levantó en la ensenada de Bolonia a finales de siglo II a. de C; convirtiéndose pronto en una ciudad de cierta pujanza en el marco de la Bética romana.

En el siglo I d. de C. la ciudad alcanzó su máximo apogeo. La economía de Baelo Claudia giraba en torno a la industrialización y comercialización de la pesca. El pescado salado y las salsas derivadas del mismo (garum) fueron sus principales productos de explotación. A finales del siglo II d. de C. se inicia el declive económico de la ciudad, motivado probablemente por las crisis económicas y sociales

\section{INTRODUCTION}

The city of Baelo Claudia, situated in the south-west of the province of Cádiz, was built in the Bolonia cove at the end of the 2nd century $B C$ and it soon became $a$ city with a certain power within the Roman Baetica.

In the 1st century $A D$ the city reached the peak of its development. The Baelo Claudia economy turned round the industrialization and commercialization of fishing. The salt water fish and the sauces derived from it ("garum") were its principal exploitation products. By the end of the 2nd century $A D$ the economic decline of the city had begun, probably motivated by the economic and social crises that took place in the 
acaecidas en el Imperio durante ese siglo. El abandono de las ciudades y el terremoto que, con casi total certeza, debió de sufrir la ciudad iniciaron el largo proceso de decadencia y deterioro de esta ciudad (1).

En la ciudad de Baelo Claudia, los capiteles y paredes estaban estucadas. La calcarenita, roca existente donde se ubica la ciudad de Baelo Claudia, es débil y quebradiza, mostrando baja cohesión y elevada porosidad. Los arquitectos y artesanos romanos emplearon distintos materiales artificiales de construcción con objeto de proteger dicha piedra de la agresión externa (ambientes marinos, fuertes vientos, etc.). Estos materiales, denominados estucos, tenían, por tanto, no sólo una misión decorativa sino también protectora de la superficie de la piedra. Los estucos, en algunas ocasiones, estaban policromados (2).

En la actualidad quedan restos de los estucos romanos originales. El objetivo del presente trabajo fue conocer la composición química y mineralógica de los distintos estucos existentes en la ciudad de Baelo Claudia, así como determinar las principales causas de su deterioro.

\section{METODOLOGÍA DE ANÁLISIS DE LOS MATERIALES}

Se tomaron muestras de estucos y otros materiales artificiales (hormigones) en distintas zonas del actual Conjunto Arqueológico. En la figura 1 se presenta un esquema de la ciudad, donde se indica las zonas de muestreo.

Todas las muestras fueron examinadas a la lupa, destacándose las diferencias observadas en los distintos estucos relativas a:

a) naturaleza y tamaño de los áridos,

b) textura y uniformidad del ligante,

c) presencia de fisuras,

d) desarrollo y disposición de crecimientos biológicos.

Tras dicho análisis, se seleccionaron algunos estucos y hormigones que evidenciaban naturalezas y grados de alteración distintos. Con objeto de caracterizar dichos materiales, así como determinar los productos de alteración presentes, se procedió con la metodología que se describe a continuación.

Una fracción de cada muestra seleccionada fue sometida a un proceso de molienda completa, hasta que el tamaño de las partículas fuera inferior a $88 \mu \mathrm{m}$.

Sobre las muestras molidas se realizaron los siguientes ensayos:
Empire during that century. The desertion of the cities and the earthquake that this city almost certainly must have suffered initiated the large process of its decadence and deterioration (I).

In the city of Baelo Claudia the capitals and walls were stuccoed. Calcarenite, the rock existing on the location of Baelo Claudia, is weak and brittle, with low cohesion and high porosity. The Roman architects and craftsmen used different artificial building materials in order to protect the stone from the external aggression (marine environment, strong winds, etc.). These materials, called stuccos, had therefore not only a decorative mission but also one of protecting the stone surface. On some occasions these stuccos were polychromatic (2).

At present remains of the original Roman stuccos can be found. The aim of this work was to know the chemical and mineralogical composition of different stuccos existing in the city of Baelo Claudia as well as to determine the principal causes of its decay.

\section{MATERIAL ANALYSIS METHODOLOGY}

Samples of stuccos and other artificial materials (concretes) were taken in different areas of the present Archeaological Site. Figure 1 presents a scheme of the city with the areas of sampling marked.

All the samples were examined under the stereo microscope. The differences observed in various stuccos refer to:

a) nature and size of the aggregate

b) binder texture and uniformity

c) presence of cracks

d) development and arrangement of biological organisms

After this analysis some stuccos and concretes which presented different natures and degrees of alteration were chosen. The following methodology was then applied in order to perform the characterization of the said materials as well as determine the present products of alteration.

A fragment of each sample was submitted to a process of complete grinding until reaching the particle size inferior to $88 \mu \mathrm{m}$.

The following tests were carried out on the ground samples: 


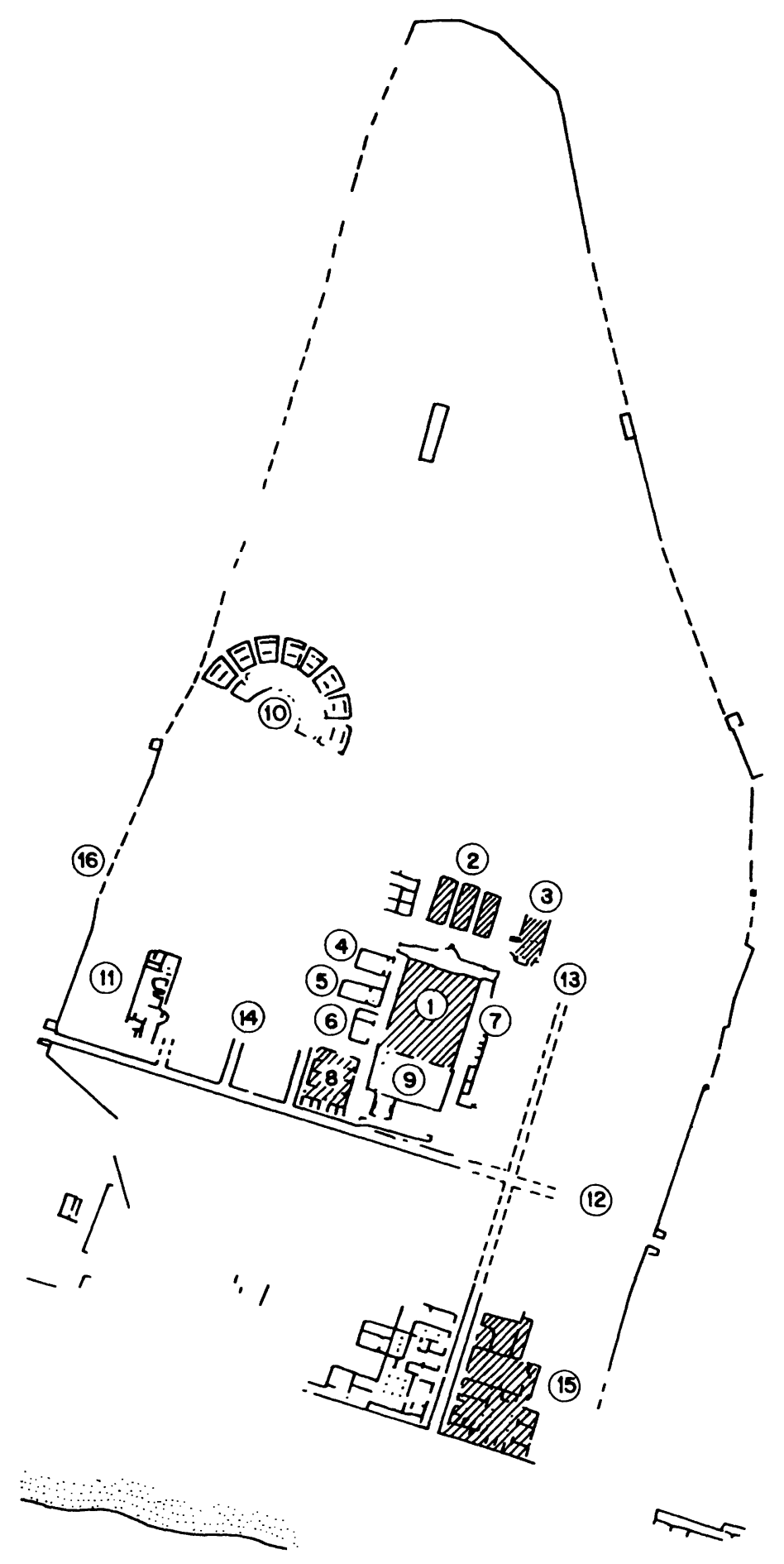

4 Teotro

Fig. 1.- Plano de la Ciudad Romana de Baelo Claudia

1.- Foro. 2.- Templos Capitolinos. 3.- Templo de Isis. 4.- Santuario.

5.- Curia. 6.- Sala de reunión. 7.- Tabernae. 8.- Mercado. 9.- Basílica. 10.- Teatro. 11.- Termas. 12.- Decumanus. 13.- Cardo. 14.- Cardines. 15.- Factorías. 16.- Muralla. 
*Análisis mineralógico por Difracción de Rayos X (DRX).

*Determinación del contenido de sales solubles en agua.

*Determinación cuantitativa de los iones inorgánicos (aniones y cationes) de esas sales solubles, por cromatografía iónica.

Sobre trozos enteros de esas mismas muestras se realizaron los siguientes ensayos:

*Análisis por microscopía óptica de luz transmitida en lámina delgada.

*Determinación de la porosidad accesible al agua y densidad aparente.

\section{RESULTADOS}

\section{MORFOLOGÍA DE LOS ESTUCOS Y HORMIGONES}

El exámen realizado a través de la lupa ha puesto en evidencia algunas diferencias significativas en los estucos y hormigones estudiados.

El estuco BC-1 (de una columna del Foro) presenta la superficie colonizada por diversos tipos de líquenes (ver figura 2).

Aparte de las formaciones biológicas, observadas en la superficie, este estuco presenta también crecimientos endolíticos a distintas profundidades. La figura 3 muestra este fenómeno. En dicha foto se observan dos crecimientos endolíticos, uno a pocas micras de la superficie y otro a unos $50 \mathrm{~mm}$ de la misma.

Este estuco presenta, también, una gran cantidad de fisuras, algunas de gran tamaño, así como una mala adherencia entre el ligante y las partículas de árido. La parte interna del estuco presenta una baja cohesión ligante-árido.

El estuco BC-3 (Templo de Isis), a diferencia de lo observado en el estuco BC-1, su superficie no presenta colonización por algas o líquenes, tal y como puede observarse en la figura 4. En este estuco también hay crecimiento de tipo endolítico, pero en mucha menor proporción a lo observado en el estuco BC-1. El estuco BC-3 presenta una buena cohesión ligante-árido con una superficie muy compactada, con pocos poros y fisuras. La parte interna del estuco presenta un aspecto compactado.

El estuco BC-6 (Templos del Capitolio) presenta la superficie recubierta de colonización biológica (ver
*Mineralogical X-Ray Diffraction Analysis (XRD)

*Determination of the contents of water soluble salts.

*Quantitative determination of inorganic ions (anions and cations) of those soluble salts by ionic

chromotography.

The following tests were carried out on the whole pieces of the same samples:

*The analysyis by optical microscopy by thin sections.

* Determination of the accesible water porosity and apparent density.

\section{RESULTS}

\section{MORPHOLOGY OF STUCCOS AND CONCRETES}

The examination through stereo microscope showed some important differences

in the stuccos and concretes studied.

The BC-1 stucco (from a Forum column) the surface is inhabited by various types of lichens (See Fig. 2).

Beside biological formations observed on the surface, this stucco also presents endolithic growths at different depths. The Fig. 3 shows this phenomenon; in it endolithic growths can be observed, one at few scarce micra from the surface and the other at a depth of 50 $m m$.

This stucco also had a great number of cracks, some large in size, as well as poor bond between the binder and the aggregate particles. The interior part of the stucco presented low binder-aggregate cohesion.

The BC-3 stucco (Isis Temple) in contrast to what was observed in the BC-1 stucco, this surface is not inhabited by algae or lichens, as can be seen in Fig. 4 . This stucco also has endolithic-type growth but on a much smaller scale than that observed in BC-1 stucco. The BC-3 stucco has a good binder-aggregate cohesion, with a very compacted surface with few pores and cracks. The interior part of the stucco has a compacted look.

The BC-6 stucco (Capitol Temples) surface covered with biological colonies (see Fig. 5). The state of the 
figura 5). El estado del estuco es de elevada desintegración, con falta de cohesión ligante-árido y un gran número de fisuras de gran tamaño. Sin embargo, se observa poco crecimiento biológico de tipo endolítico. La parte interna del estuco se encuentra arenizada y altamente atacada.

El estuco BC-7 (Templos del Capitolio) presenta su superficie completamente colonizada por microorganismos. Este estuco está muy alterado; parte del ligante ha desaparecido, destacándose las partículas de árido (figura 6). Hay muy poco crecimiento de tipo endolítico. La parte interna del estuco se encuentra arenizada, y su adherencia a la piedra soporte es muy mala.

El estuco BC-8 (Templos del Capitolio) presenta una superficie muy blanca y homogénea con ausencia de ataque biológico (figura 7). Su cohesión liganteárido es elevada; en algunas zonas se observan dos capas: la superior uniforme y compacta, como la descrita anteriormente, y la inferior menos uniforme y compactada. Parece que la capa externa es un acabado superficial del mortero que le protege de la agresión externa.

En este estuco se observa, en la parte interna, crecimiento endolítico a pocas micras de la superficie. La zona interna del estuco está más cohesionada y menos deteriorada que las observadas en los estucos BC-6 y BC-7. Sin embargo, también se observan algunos fenómenos de arenización $\mathrm{y}$, sobre todo, gran cantidad de partículas filamentosas, restos de una actividad liquénica.

\section{El hormigón $B C-17$ (Factoria de Garum) su} superficie externa está colonizada de depósitos negros y amarillo-naranja (figura 8). No se observó la presencia de organismos endolíticos. El hormigón presenta áridos de diferente naturaleza (ladrillos machacados, bioclastos, calizas, etc). La cohesión ligante-árido es variable en el hormigón, presentando fisuras de gran tamaño.

\section{ANÁLISIS MINERALÓGICO POR DIFRACCIÓN DE RAYOS X}

En la Tabla I se muestran los resultados obtenidos tras el análisis realizado a los estucos y hormigones por DRX.

De este análisis se deduce que el componente mineralógico mayoritario, en todas las muestras, es el $\mathrm{CaCO}_{3}$ en forma de cálcita. En los estucos BC-1, BC-3 y BC-4 junto a la calcita se encuentra $\alpha-\mathrm{SiO}_{2}$ (cuarzo), aunque con relativa baja proporción; $\mathrm{CaMg}\left(\mathrm{CO}_{3}\right)_{2}$ (dolomita) se detecta en BC-3 y BC-4 a nivel de trazas. stucco is one of advanced disintegration without any binder-aggregate cohesion and a great number of large size cracks. Nevertheless; there is little biological endolithic-type growth. The interior part of the stucco is sandy and strongly attacked.

The BC-7 stucco (Capitol Temples) the surface is completely covered with microorganisms. This stucco is greatly altered; a part of the binder has disappeared, leaving the aggregate particles exposed (Fig. 6). There is wery little endolithic-type growth. The interior part of the stucco is sandy, and its bond with the support stone is very poor.

The BC-8 stucco (Capitol Temples) very white and homogenous surface with no biological attack (Fig.7). High binder-aggregate cohesion; two layers are observed in some areas, the upper one uniform and compact, as described previously, and the lower less uniform and compacted. The exterior layer seems to be a superficial mortar finish aimed at protecting the surface from the external aggression.

In the interior part of this stucco endolithic growth can be observed at few micra from the surface. The interior area of the stucco is more compacted and less damaged than those observed in the $B C-6$ and $B C-7$ stuccos. Nevertheless, some disintegration phenomena can be observed and, above all, a large amount of filamentous particles, remains of an activity of the lichens.

The BC-17 concrete (Garum Factory) the external surface has black and yellow-orange sediments Fig. 8). No endolithic organisms were observed. The concrete has various types of aggregate (crushed brick, bioclasts, limestones, etc.) The binder-aggregate cohesion is variable in the concrete, with large cracks.

\section{MINERALOGICAL ANALYSIS BY X-RAY DIFFRACTION}

Table I shows the results obtained through the analysis of stuccos and concretes by XRD.

This analysis leads us to the conclusion that the prevailing mineralogical component in all the samples is $\mathrm{CaCO}_{3}$ in the form of calcite. In the $\mathrm{BC}-1, \mathrm{BC}-3$ and $B C-4$ stuccos, together with calcite there is $\alpha-\mathrm{SiO}_{2}$ (quartz) although in a relatively small proportion ; traces of $\mathrm{CaMg}\left(\mathrm{CO}_{3}\right)_{2}$ (dolomite) are detected in $\mathrm{BC}^{-}-3$ 


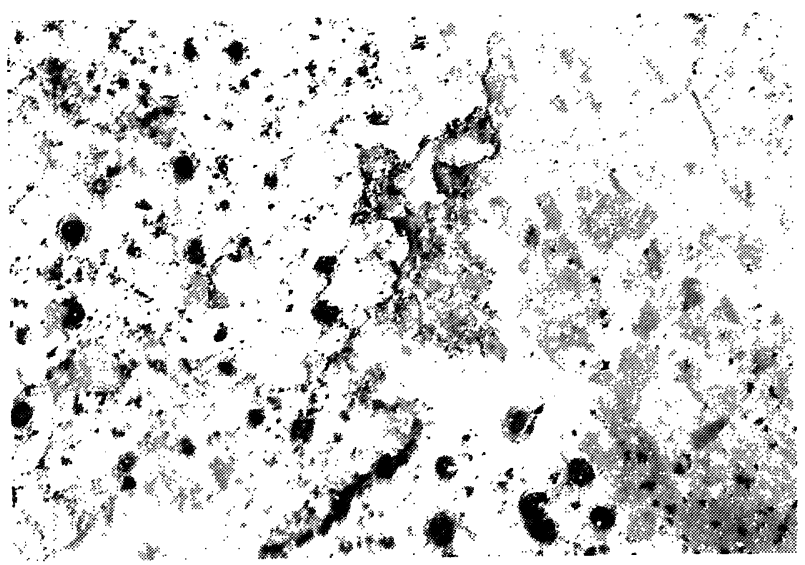

Fig.2.- Estuco del Foro (BC-1). Detalle de la superficie. Presencia de líquenes.

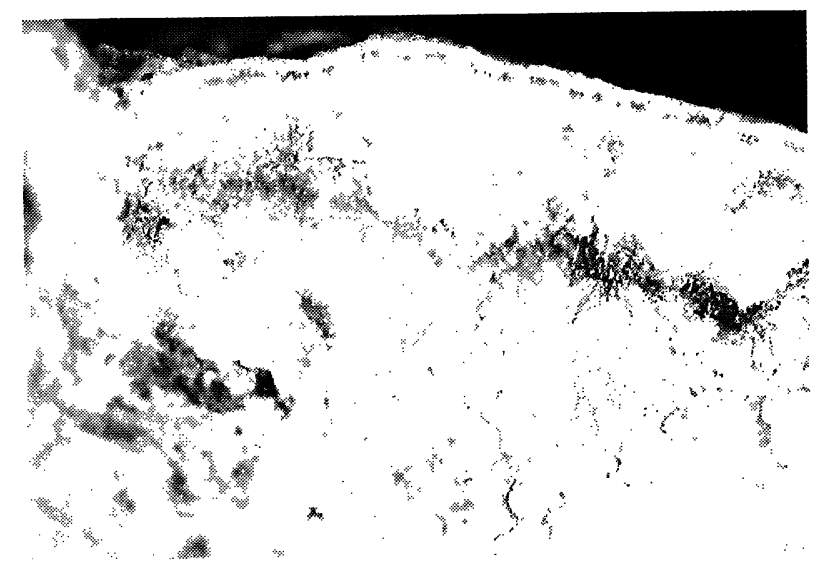

Fig.3.- Crecimiento endolítico en estuco del Fofo (BC-1).

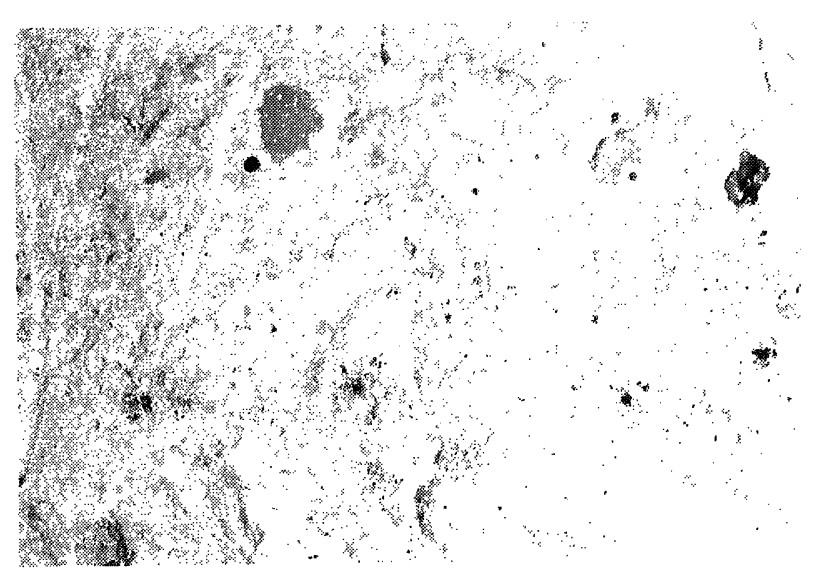

Fig.4.- Estuco del Templo de Isis (BC-3). Detalle de la superficie.

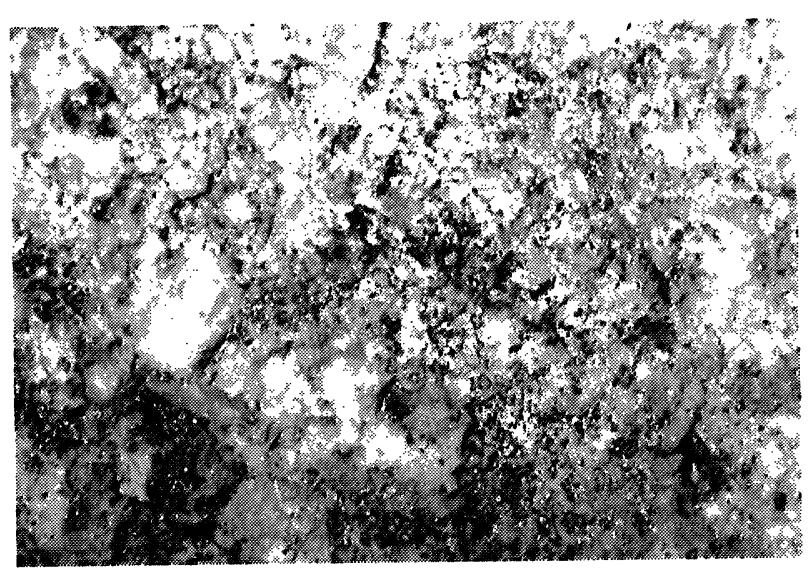

Fig. 6.- Estuco de Templos del Capitolio (BC-7). Detalle de la superficie. Colonización biológica.

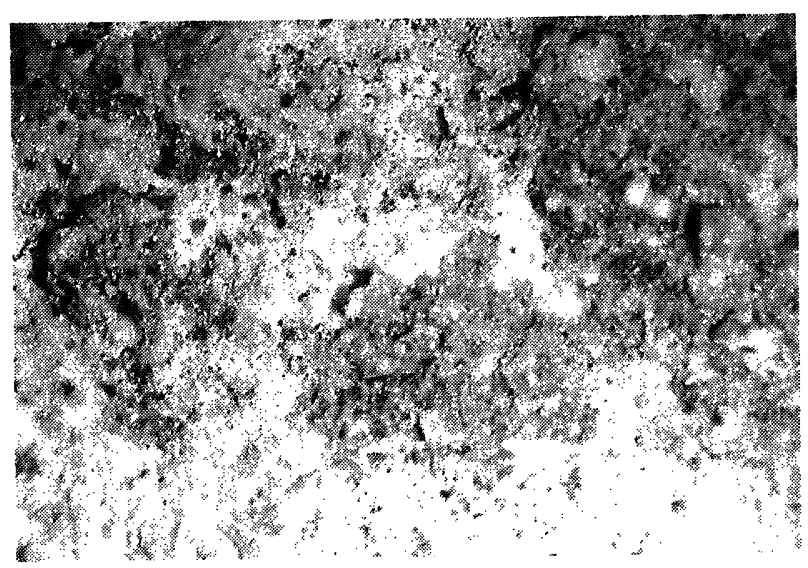

Fig.5.- Estuco de Templos del Capitolio (BC-6). Superficie con colonización biológica.

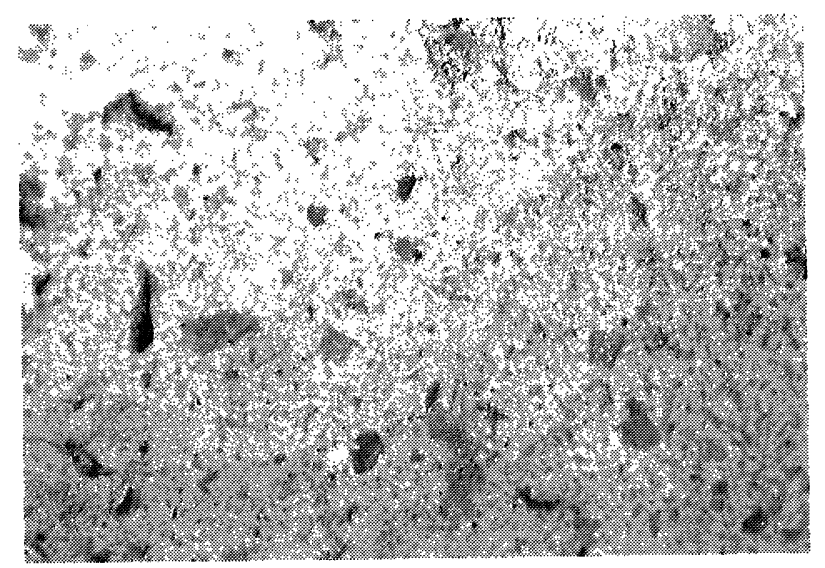

Fig.7.- Estuco de Templos del Capitolio (BC-8). Superficie de estuco sin colonización biológica. 
TABLA I

Composición Mineralógica de los Estucos y Hormigones por DRX

\begin{tabular}{|c|c|c|c|c|c|c|}
\hline Muestra & Cuarzo & Calcita & Dolomita & Feldesp. & Micas & Clinoclor \\
\hline$B C-1$ & + & $+t+$ & - & -- & -- & -- \\
\hline $\mathrm{BC}-3$ & + & $++t$ & 0 & -- & -- & - \\
\hline$B C-4$ & ++ & +++ & $t^{\prime}$ & -- & - & - \\
\hline BC- 6 & ++ & $++t$ & ++ & -- & -- & -- \\
\hline$B C-7$ & ++ & $+t+$ & $+t+$ & 0 & -- & 0 \\
\hline$B C-8$ & 0 & $++t$ & ++ & -- & -- & -- \\
\hline$B C-17$ & ++ & $+t+$ & o & + & + & + \\
\hline$B C-18$ & ++ & $++t$ & o & ++ & + & + \\
\hline
\end{tabular}

++ abundante $\quad++$ moderado

Del resultado se deduce que el ligante de estos estucos es la cal con áridos muy probablemente de naturaleza caliza (fundamentalmente calcitas y, en muy baja proporción, dolomitas)

En los estucos BC-6, BC-7 y BC-8 hay mayor cantidad de dolomita, llegando a ser en BC-8 fase mayoritaria junto a la calcita. También hay presencia de $\alpha-\mathrm{SiO}_{2}$. Al igual que en los estucos anteriormente mencionados el material ligante es la cal. En este caso los áridos también son calizos, pero en éste hay tanto calcitas como dolomitas.

Los hormigones $\mathrm{BC}-17$ y BC-18 tienen composiciones mineralógicas muy similares. Junto a la calcita se encuentran cuarzo, feldespatos, micas y clinoclores.

\section{ANÁLISIS PETROGRÁFICO POR MICROSCOPÍA ÓPTICA DE LUZ TRANSMITIDA (LÁMINA DELGADA)}

En la figura 9 se muestra el aspecto general del estuco $B C-I$ en su análisis por microscopía óptica de luz

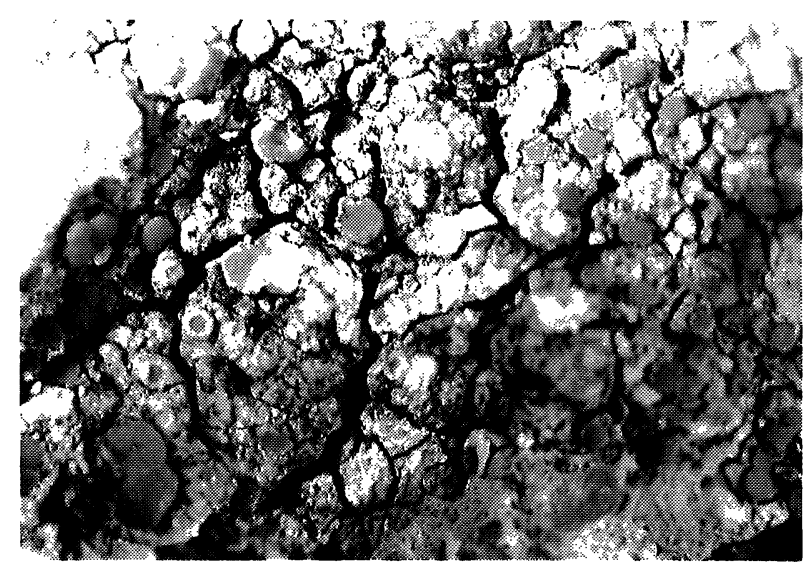

Fig.8.- Hormigón del Garum (BC-17). Colonización masiva de líquenes en la superficie. and $B C-4$. What can be deduced from these results is that the binder of these stuccos is lime with aggregates most probably of limestone nature (basically calcites and dolomites in a very small proportion).

In the $B C^{-}-6, B C-7$ and $B C-8$ stuccos there is a greater amount of dolomite, and in $B C^{\prime}-8$ it is predominant together with calcite. There is also $\alpha-\mathrm{SiO}_{2}$. The same as in the previously mentioned stuccos the binding material is lime. In this case the aggregates are also of limestone nature only here there are as much calcites as dolomites.

The BC-17 and BC-18 concretes have very similar mineralogical compositions. Together with calcite there is quartz, felspars, glimmers and clinoclores.

\section{PETROGRAPHIC ANALYSIS BY OPTICAL MICRISCOPY (THIN SECTIONS)}

Figure 9 shows the general look of the BC-1 stucco in its analysis by optical microscopy. This analysis

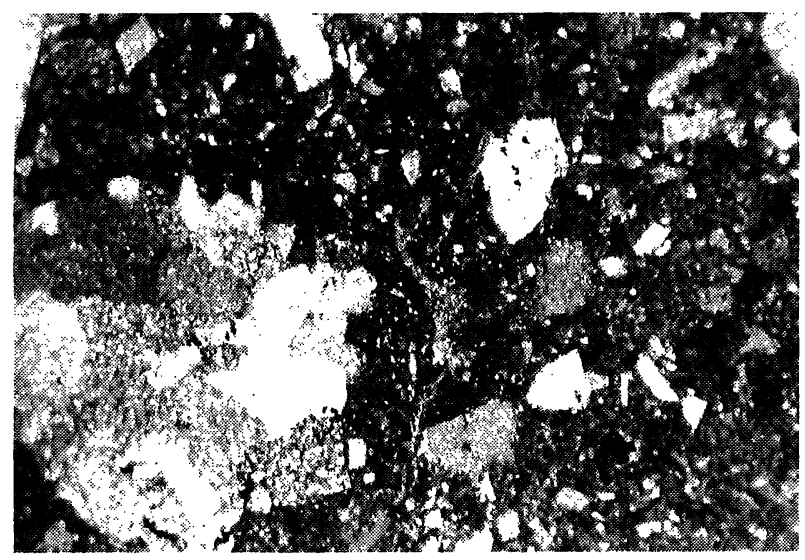

Fig.9.- Lámina delgada estuco del Foro (BC-1). 
transmitida. En dicho análisis se puede observar que los áridos son de gran tamaño y de naturaleza caliza, mayoritariamente de calcita. El diámetro medio de los áridos es de 0,9 mm. Estos áridos presentan planos de exfoliación, lo que está indicando que proceden del machaqueo de rocas o muy probablemente de mármoles. Algunos de los lados de estos áridos aparecen con signos de corrosión. Hay presencia de cuarzo dendrítico, pero en baja proporción.

Respecto al ligante, éste se manifiesta bastante uniforme. La coloración oscura que se observa al microscopio puede ser debida a su naturaleza microcristalina. La dosificación árido/ligante se puede estimar del orden de 3-4/1.

La figura 10 muestra el aspecto del estuco $B C-3$. Se observa que el tamaño y la proporción de los áridos en este estuco es sensiblemente inferior al observado en el estuco BC-1, con un diámetro medio de $0,2 \mathrm{~mm}$. Todos estos áridos son calizos, mayoritariamente de calcita.

El ligante, $\mathrm{CaCO}_{3}$, tiene una elevada homogeneidad. En algunas zonas de la matriz se observa la presencia de fisuras que presentan en su interior recristalizaciones tardías de carbonato cálcico. Estas recristalizaciones tienen un efecto positivo, ya que actúan como relleno de poros o fisuras. En este estuco la relación árido/ligante es muy baja del orden de 1/4.

El aspecto del estuco $B C-7$ se puede observar en la figura 11. El tamaño de los áridos es muy variado, llegando a tener algunos hasta un diámetro de $0,6 \mathrm{~mm}$. La naturaleza de los áridos es caliza, con presencia tanto de calcita como de dolomita. Al igual que lo indicado en $\mathrm{BC}-1$, los áridos proceden muy probablemente del machaqueo de rocas calcáreas o mármoles, ya que los áridos se presentan en planos de exfoliación. Se observa también que algunas partículas de árido han experimentado procesos corrosivos en su contacto con el ligante, dando lugar a nuevas recristalizaciones que pueden favorecer la adherencia entre ambos materiales. Se observa la presencia de cuarzo dentrítico en baja proporción.

El ligante está basado en $\mathrm{CaCO}_{3}$. En éste la dosificación árido/ligante es muy superior a la observada en el estuco BC-3, y se puede estimar del orden de $4 / 1$.

La figura 12 muestra el aspecto del estuco BC-8. Los áridos tienen al igual que en el estuco BC-7 un tamaño muy variado. Su naturaleza es fundamentalmente caliza con partículas tanto de calcita como de dolomita. Hay también cuarzo dendrítico en baja proporción. Por la forma que presentan los áridos enables us to observe that the aggregates have large size and limestone nature, predominantly calcite. The average diameter of these aggregates is of $0.9 \mathrm{~mm}$. These aggregates show signs of exfoliation, which means they originate from rock crushing or quite probably marbles. Some sides of these aggregates present signs of corrosion. There is dendritic quartz although in a small proportion.

As for the binder, it appears quite uniform. Dark colouring observed under the microscope may be due to its microcrystalline nature. The aggregate/binder dosage is estimated to be about 3-4/1.

Figure 10 shows the look of the BC-3 stucco. We can see that the size and the proportion of the aggregates in this stucco is considerably smaller than that observed in $B C-1$ stucco, with an average diameter of $0.2 \mathrm{~mm}$. All these aggregates are of limestone, mostly calcite.

The binder, $\mathrm{CaCO}_{3}$, is highly homogenous. In some areas of the matrix we can notice the presence of cracks which in their interior have late recrystallizations of calcium carbonate. These recrystallizations have a positive effect because they act as filler of pores and cracks. This stucco has a very low aggregate/binder ratio, namely about 1/4.

The look of BC-7 stucco can be seen in Fig. 11. The size of the aggregates varies a lot, some of them reaching even $0.6 \mathrm{~mm}$. The nature of the aggregate is limestone, with both calcite and dolomite present. The same as in BC-1, the aggregates most probably originate from the crushing of calcareous rock or marbles since they show signs of exfoliation. We can also observe that some aggregate particles have undergone corrosion processes in contact with the binder, which has led to new recrystallizations that can favour the bond between these two materials. Dendritic quartz is present in a small proportion.

The binder is based on $\mathrm{CaCO}_{3}$. In this stucco the aggregate/binder dosage is quite superior to that observed in the BC-3 stucco, namely about 4/1.

Figure 12 shows the look of BC-8 stucco. The aggregates have various sizes as in the BC-7 stucco. Their nature is basically limestone with particles of both calcite and dolomite. There is also dendritic quartz in a small proportion. Judging by the form in which the limestone aggregates come, they originate, 
calizos éstos proceden, al igual que en los casos anteriores, del machaqueo de rocas calcáreas. Asímismo se observan zonas en donde las partículas de árido han sufrido procesos de corrosión.

En la matriz ligante se observan algunas fisuras en cuyo interior se ha producido recristalizaciones de calcita. En dicho estuco la dosificación árido/ligante se puede estimar del orden de $2-3 / 1$.

La figura 13 muestra el aspecto del hormigón BC-17. Se observan tres capas claramente diferenciadas: La de la izquierda corresponde a una partícula de árido

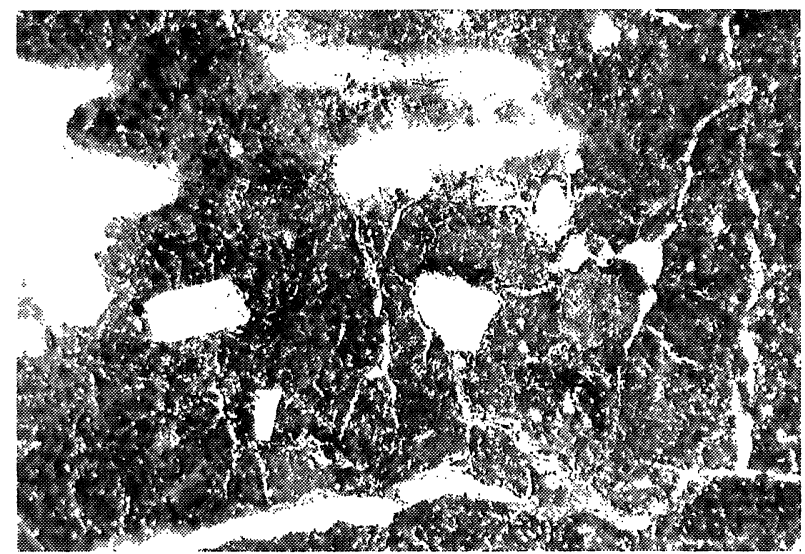

Fig.10.- Estuco del Templo de Isis. Detalle de la matriz y áridos pequeños.

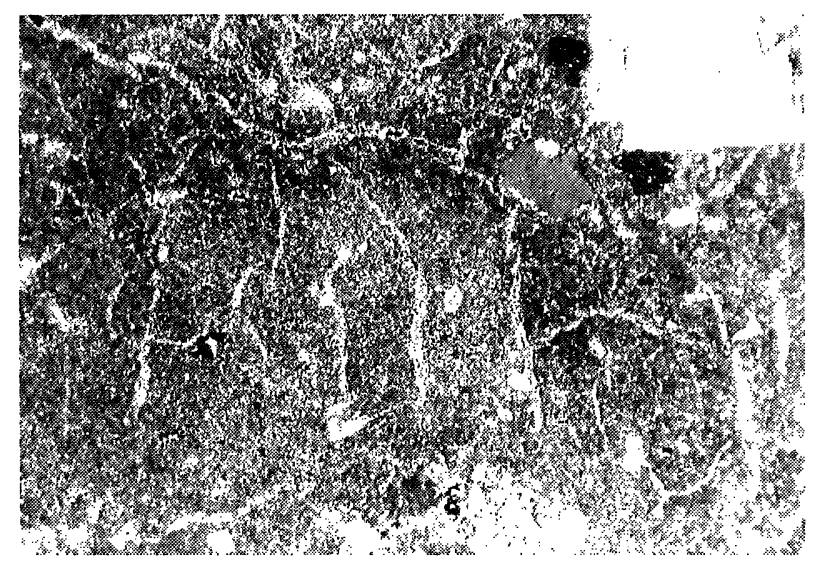

Fig. 12.- Estuco de los Templos del Capitolio (BC-8). Aspecto de la matriz calcárea. Recristalizaciones de carbonato en las fisuras. the same as in the previous cases, from the crushing of calcareous rocks. There are also areas where it can be observed that the aggregate particles have undergone corrosion processes.

In the binding matrix there are some cracks in whose interior calcite recrystallization occured. In this stucco the aggregate binder dosage is estimated to be of about 2-3/1.

Figure 13 shows the look of $B C-17$ concrete. Three layers can clearly be distinguished. The one on the left corresponds to a ceramic aggregate particle coming

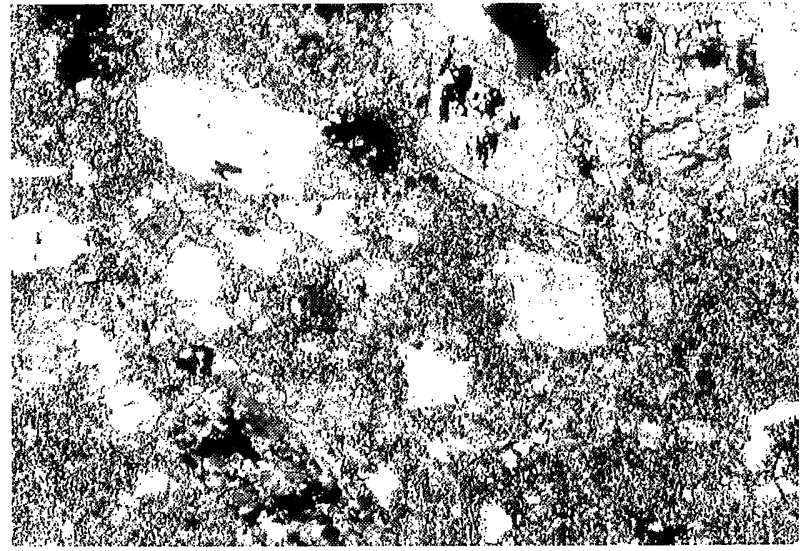

Fig.11.- Estuco de los Templos del Capitolio (BC-7). Áridos calizos de gran tamaño.

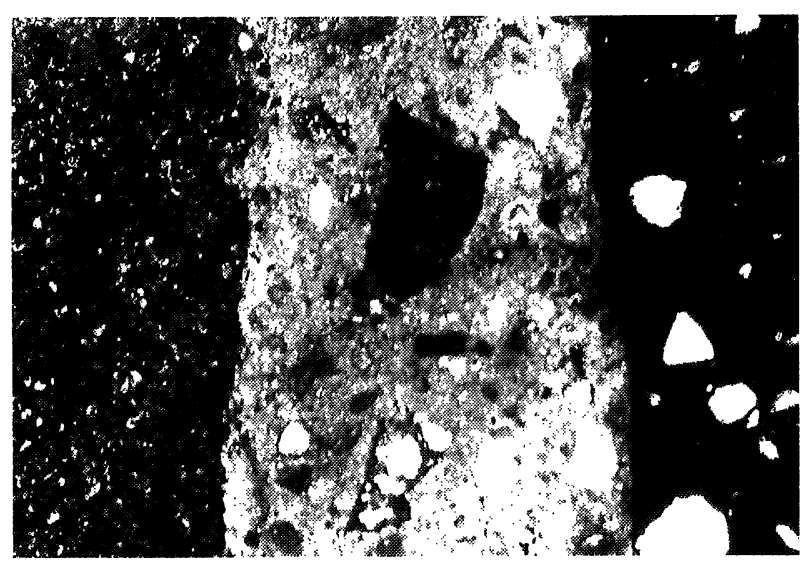

Fig. 13.- Hormigón del Garum (BC-17). Diferenciación de las distintas capas del hormigón. 
cerámico procedente del machaqueo de un ladrillo. La zona central corresponde a ligante $\left(\mathrm{CaCO}_{3}\right)$ junto a partículas de árido de menor tamaño, de distinta naturaleza, ya que se observan calizas, feldespatos, cuarzos, micas, etc. Finalmente, la zona de la derecha corresponde a una partícula de bioclastos que actúa también como árido en este hormigón.

\section{CONTENIDO DE SALES SOLUBLES EN AGUA. CUANTIFICACIÓN DE LOS IONES INORGÁNICOS PRESENTES POR CROMATOGRAFÍA IÓNICA}

En la Tabla II se presentan los contenidos de sales solubles en agua, así como las concentraciones de los aniones y cationes inorgánicos presentes en dichas sales.

De dicha tabla se deduce que los estucos y hormigones estudiados tienen bajos contenidos en sales solubles en agua (en todos los casos inferiores al $1 \%$ en peso). El anión, presente en mayores concentraciones en todas las muestras, excepto en $\mathrm{BC}-8$, es el $\mathrm{Cl}^{-}$. En $\mathrm{BC}-8$ es el $\mathrm{SO}_{4}^{2-}$ la especie aniónica mayoritaria.

Respecto a los cationes, el $\mathrm{Ca}^{2+}$ es el ión mayoritario en todas las muestras. Los contenidos en $\mathrm{Na}^{+}, \mathrm{Mg}^{2+}$ y K son relativamente bajos.

\section{POROSIDADES ACCESIBLES AL AGUA Y DENSIDADES APARENTES}

Las porosidades accesibles al agua y las densidades aparentes de los estucos y hormigones se han determinado de acuerdo a las Recomendaciones dadas por RILEM (3).

Los resultados obtenidos se muestran en la Tabla III.

El material más poroso es el hormigón $\mathrm{BC}-17$, sin embargo, presenta una densidad aparente relativamente alta. La elevada porosidad puede ser debida a que este hormigón fue elaborado con áridos de tamaño muy grueso; en algunos casos su diámetro es superior a los 2 $\mathrm{cm}$. Pese a ello, el material conserva una elevada compacidad y cohesión interna que se manifiesta por la alta densidad aparente.

Por el contrario, el estuco BC-1 presenta también una elevada porosidad, pero tiene así mismo una baja densidad, lo que está indicando un material de baja cohesión interna.

Los restantes materiales presentan porosidades medias, comprendidas entre $24-26 \%$ y densidades aparentes entre $2,40-2,65 \mathrm{~g} / \mathrm{cm}^{3}$. from a crushed brick. The central area corresponds to the binder ( $\mathrm{CaCO}$ ) together with smaller particles of different nature, since limestone, quartzs, felspars, glimmers, etc. are observed. Finally, the area on the right corresponds to a particle of bioclasts which also acts as aggregate in this concrete.

\section{WATER SOLUBLE SALTS CONTENTS. QUANTIFICATION OF INORGANIC IONS PRESENT BY IONS CROMATOGRAPHY}

Table II shows the contents of water soluble salts as well as the concentrations of inorganic anions and cations present in the said salts.

From this table we can deduce that the studied stuccos and concretes have low contents of water soluble salts (in all cases they are inferior to $1 \mathrm{wt}$. \%) The anion present in greatest concentrations in all the samples except in $\mathrm{BC}-8$, is $\mathrm{Cl}$. In $\mathrm{BC}-8$ the predominant anion is $\mathrm{SO}_{4}{ }^{2-}$.

As for the cations, the predominant one in all the samples is $\mathrm{Ca}^{2+}$. The $\mathrm{Na}^{+}, \mathrm{Mg}^{2+}$ and $\mathrm{K}^{+}$contents are relatively small.

\section{ACCESSIBLE WATER POROSITIES AND APPARENT DENSITIES}

The accessible water porosities and the apparet densities in the stuccos and concretes have been determined according to the Recommendations given by RILEM (3)

The results obtained are shown in Table III.

The most porous material is the BC-17 concrete; nevertheless it shows a relatively high apparent density. The high porosity may be due to the fact that this concrete was made of aggregate of large size, in some cases the diameter reaches $2 \mathrm{~cm}$. In spite of this, the material maintains a high level of compactness and interior cohesion which shows through the high apparent density.

In contrast to this, the BC-1 stucco also has high porosity but at the same time has low density which points to a poor interior cohesion of the material.

The rest of the materials have medium porosities of between 24 and $26 \%$ and apparent densities of between 2.40 and $2.65 \mathrm{gr} / \mathrm{cm}^{3}$. 
TABLA ॥

Contenido en sales solubles en agua en los estucos y hormigones.

\begin{tabular}{|c|c|c|c|c|c|c|c|c|c|c|}
\hline Muestra & $\begin{array}{c}\mathrm{Cl}^{-} \\
\text {(\%peso) }\end{array}$ & $\begin{array}{l}\mathrm{NO}_{3}^{-} \\
(\%)\end{array}$ & $\begin{array}{c}\mathrm{SO}_{4}{ }^{2-} \\
(\%)\end{array}$ & $\begin{array}{c}\mathrm{C}_{2} \mathrm{O}_{4}{ }^{2-} \\
(\%)\end{array}$ & $\begin{array}{l}\mathrm{Na}^{+} \\
(\%)\end{array}$ & $\begin{array}{l}K^{+} \\
(\%)\end{array}$ & $\begin{array}{c}\mathrm{NH}_{4}{ }^{1+} \\
(\%)\end{array}$ & $\begin{array}{c}\mathbf{M g}^{2+} \\
(\%)\end{array}$ & $\begin{array}{l}\mathrm{Ca}^{2+} \\
(\%)\end{array}$ & $\begin{array}{l}\text { Tota } \\
\% \text { s.s. }\end{array}$ \\
\hline$B C-1$ & 0,04 & -- & 0,02 & 0,05 & 0,02 & 0,01 & -- & 0,01 & 0,49 & 0,69 \\
\hline BC-3 & 0,06 & -- & 0.01 & -- & 0,02 & 0,01 & 0,01 & -- & 0,35 & 0,46 \\
\hline$B C-4$ & 0,06 & -- & 0,01 & -- & 0,02 & 0,01 & 0,01 & 0,01 & 0,51 & 0,63 \\
\hline BC- 6 & 0,13 & 0,12 & 0,02 & -- & 0,01 & -- & -- & 0,01 & 0,54 & 0,82 \\
\hline$B C-7$ & 0,07 & 0,01 & 0,05 & -- & 0,04 & 0,01 & 0,01 & 0,03 & 0,60 & 0,82 \\
\hline BC-8 & 0,07 & 0,01 & 0,12 & 0,06 & 0,02 & 0,01 & -- & 0,01 & 0,47 & 0,76 \\
\hline BC-18 & 0,06 & -- & 0,02 & -- & 0,02 & .- & -- & 0,02 & 0,20 & 0,32 \\
\hline
\end{tabular}

TABLA III

Porosidad Accesible al Agua y Densidad Aparente de los Estucos y Hormigones de Baelo Claudia

\begin{tabular}{||c|c|c||}
\hline Muestra & $\begin{array}{c}\text { Porosidad Accesible } \\
\text { Agua (\%) }\end{array}$ & $\begin{array}{c}\text { Densidad Aparente } \\
\left(\mathbf{g r} / \mathrm{cm}^{3} \text { ) }\right.\end{array}$ \\
\hline BC-1 & $30,80 \pm 0,10$ & $2,25 \pm 0,05$ \\
\hline BC-3 & $26,09 \pm 0,04$ & $2,65 \pm 0,01$ \\
\hline BC-4 & $26,40 \pm 0,04$ & $2,42 \pm 0.01$ \\
\hline BC-6 & $25,82 \pm 0,04$ & $2,62 \pm 0,01$ \\
\hline BC-7 & $23,90 \pm 0,10$ & $2,65 \pm 0,05$ \\
\hline BC-8 & $24,40 \pm 0,04$ & $2,61 \pm 0,01$ \\
\hline BC-17 & $34,72 \pm 0,03$ & $2,59 \pm 0,01$ \\
\hline
\end{tabular}

\section{INTERPRETACIÓN DE LOS RESULTADOS}

\section{NATURALEZA Y COMPOSICIÓN DE LOS ESTUCOS Y HORMIGONES ROMANOS DE BAELO CLAUDIA}

\section{Respecto a los estucos}

Los estucos son aquellos materiales artificiales de construcción que se emplearon para recubrir y decorar las rocas en los edificios romanos.

La roca calcarenita existente en la zona donde se ubica la ciudad de Baelo Claudia, es débil y quebradiza, mostrando baja cohesión y elevada porosidad. Los arquitectos y artesanos romanos emplearon distintos materiales artificiales de construcción, con objeto de proteger dicha piedra de la agresión externa (ambiente

\section{INTERPRETATION OF THE RESULTS}

NATURE AND COMPOSITION OF THE ROMAN STUCCOS AND CONCRETES OF BAELO CLAUDIA

\section{Regarding the stuccos}

Stuccos are those artificial building materials which were used to cover and decorate the rocks in Roman buildings.

Calcarenite, the rock existing in the area where the city of Baelo Claudia is located, is weak and brittle with low cohesion and high porosity. Roman architects and craftsmen used different artificial building materials in order to protect this stone from the exterior aggression (marine environment, strong winds, 
marino, fuertes vientos, etc) . Estos materiales, denominados estucos, tenían, por tanto, no sólo una misión decorativa, sino también protectora de la superficie de la piedra.

El material ligante en todos los estucos romanos estudiados es la cal o $\mathrm{CaCO}_{3}$ (calcita). Los áridos son mayoritariamente de naturaleza caliza. En función de la composición de estos áridos, se pueden distinguir dos tipos de estucos distintos:

a) Estucos con árido calizo basado únicamente en $\mathrm{CaCO}_{3}$ (calcita), como por ejemplo BC-1 (Foro) y BC3, BC-4 (Templo de Isis).

b) Estucos con árido calizo basado en $\mathrm{CaCO}_{3}$ (calcita) y $\mathrm{CaMg}\left(\mathrm{CO}_{3}\right)_{2}$ (dolomita), por ejemplo $\mathrm{BC}-6, \mathrm{BC}-7$ y BC-8 (estucos procedentes de la zona de los Templos).

Tanto en un caso como en otro los áridos aparecen con tamaños muy variables y fracturados por sus planos de exfoliación. Este fenómeno permite deducir que dichos áridos proceden muy probablemente del machaqueo de rocas calcáreas, fundamentalmente mármoles.

Las dosificaciones árido/ligante en todos estos estucos son muy variables. En algunos casos son muy ricos en ligante, como por ejemplo la muestra BC-3 (Templo de Isis), con una relación árido/ligante que se puede estimar de 1/4. Por el contrario, hay también estucos muy ricos en árido, como por ejemplo las muestras BC-1 (Foro) y BC-7 (Templo de Júpiter), en donde la relación árido/ligante se puede estimar del orden de 3$4 / 1$.

\section{Respecto a los hormigones}

Este grupo de materiales se encuentra fundamentalmente en pavimentos y zonas que no precisan requerimientos estéticos importantes. Las muestras BC-17 y BC-18 proceden de la factoría de Garum y del pavimento del Micellarium, respectivamente. En general, los hormigones extraídos presentan una elevada cohesión interna.

Los análisis realizados a estos hormigones han demostrado que el ligante está basado únicamente en cal. Los áridos son de naturaleza muy variada, ya que se han detectado ladrillos machacados, rocas calcáreas, materiales silíceos como: cuarzo, feldespatos, moscovitas, así como también partículas de bioclasas.

Todos los materiales estudiados presentan porosidades accesibles al agua, relativamente elevadas, con valores comprendidos entre el 24-35\%. Los morteros de cal son materiales que suelen presentar porosidades en esos órdenes de magnitud. etc.) These materials, called stuccos, had threfore not only a mission of decoration but also one of protection of the stone surface.

The binding material in all Roman stuccos studied is lime or $\mathrm{CaCO}_{3}$ (calcite). The aggregates are predominantly of limestone nature. Two different types of stuccos can be distinguished as a function of the composition of these aggregates:

a) Stuccos with limestone aggregate based only on $\mathrm{CaCO}_{3}$ (calcite), as for example $\mathrm{BC}-1$ (Forum) and $\mathrm{BC}$ 3, BC-4 (Isis Temple).

b) Stuccos with limestone aggregate based on $\mathrm{CaCO}_{3}$ (calcite) and $\mathrm{CaMg}\left(\mathrm{CO}_{3}\right)_{2}$ (dolomite), for example $\mathrm{BC}-6$, $B C-7$ and $B C-8$ (the stuccos from the Area of the Temples).

In both cases the aggregates appear in quite different sizes and broken by exfoliation. This phenomenon allows us to deduce that these aggregates most probably come from the crushing of calcareous rocks, basically marbles.

The aggregate/binder dosages in all these stuccos vary a lot. In some cases they are rich in binder, as in the sample of BC-3 (Isis Temple) with an aggregate/binder ratio of about 1/4. On the other hand, there are also stuccos rich in aggregate, as in the samples $B C-1$ (Forum) and BC-7 (Jupiter Temple), where the aggregate/binder ratio is of about 3-4/1.

\section{Regarding the Concretes}

This group of materials is basically found in pavements and areas that do nor require great aesthetic refinement. The samples $B C-17$ and $B C-18$ come from the Garum Factory and the Miscellarium pavement, respectively. Generally speaking, the extracted concretes have a high interior cohesion.

The analyses carried out on these concretes have shown that the binder is based solely on lime. The aggregates vary greatly from crushed brick, calcareous rocks, siliceous materials, such as quartz, felspars, muscovites as well as particles of bioclasts.

All the materials studied show relatively high accesible water porosities, with values of between $24-35 \%$ The lime mortars are the materials which usually have porosities of that order of magnitude. 


\section{CAUSAS DE DETERIORO DE LOS ESTUCOS Y HORMIGONES}

El estado de conservación de los distintos estucos y hormigones estudiados es muy variado. Algunos materiales se encontraban en un avanzado estado de deterioro, con pérdida de su cohesión interna y falta de adherencia a la piedra soporte, por ejemplo BC-1 (Foro), BC-6, BC-7 (Zona de Templos). Otros, por el contrario, presentaban una elevada cohesión y buena adherencia como: BC-3 (Templo de Isis), BC-17 (Factoria de garum), BC-18 (Macellum).

El contenido de sales solubles en agua, en los materiales estudiados es siempre inferior al $1 \%$ en peso (Ver Tabla II). Este contenido es bastante bajo, y parece indicar que no hay un problema grave por cristalización de sales. Los estucos y hormigones se encuentran en ambiente marino; pese a ello, los contenidos en $\mathrm{Cl}^{-}$y $\mathrm{Na}^{+}$son muy bajos. Los restantes iones se encuentran también en contenidos inferiores al $0,15 \%$, a excepción del $\mathrm{Ca}^{2+}$, cuyos contenidos se encuentran alrededor del 0,4-0,6\%. Este $\mathrm{Ca}^{2+}$ puede proceder de una pequeña disolución parcial de los carbonatos que forman parte tanto del ligante como de los áridos.

No se han encontrado eflorescencias en la superficie de los materiales estudiados. Esto no impide descartar la posibilidad de que se puedan formar algunos depósitos de sales en la superficie de los materiales; sin embargo, en base a los resultados obtenidos en este estudio esos depósitos se encuentran en muy pequeña proporción.

En algunos estucos se ha observado que se ha producido una pérdida del material ligante, ya que se observan los áridos muy resaltados y poco ligante entre ellos. La justificación a este fenómeno, que puede justificar también la baja proporción de sales solubles en agua, es que se puede producir un proceso de solubilización parcial en la superficie del estuco (por agua de lluvia) que arrastre no sólo a las sales solubles sino también, y de modo parcial, a la cal del ligante.

Adicionalmente, la costa de Cádiz es una zona geográfica con grandes vientos de levante que pudiendo facilitar que en los paramentos verticales se produzca el desprendimiento de partículas de ligante poco cohesionado por efecto físico y mecánico.

Uno de los fenómenos observados en el Conjunto Arqueológico de Baelo Claudia es la pérdida de adherencia de los estucos a la piedra soporte. La parte interna del estuco en contacto con la piedra se desprende y se encuentra totalmente desintegrada y arenizada. La piedra soporte (en muchos casos calcarenita, en otros calizas) es un material altamente

\section{CAUSES OF DECAY OF THE STUCCOS AND CONCRETES}

The state of preservation of the different stuccos and concretes studied is quite varied. Some materials were in an advanced state of deterioration with loss of interior cohesion and lack of bond to the support stone, as in BC-1 (Forum), BC-6, Bc-7 (The Area of the Temples). Others, on the other hand, showed high cohesion and good bond, as in BC-3 (Isis Temple), BC17 (Garum Factory), BC-18 (Macellum).

The water soluble salts contents in the materials studied is always lower than $1 \mathrm{wt}$. \% (See Table II). This is a rather low contents and seems to indicate that there is no serious problem provoked by the crystallization of salts. The stuccos and concretes are located in the marine environment and in spite of this the contents of $\mathrm{Cl}^{-}$and $\mathrm{Na}^{+}$are quite low. The contents of the rest of the ions are also inferior to $0.15 \%$, except those of $\mathrm{Ca}^{2+}$ which are of about 0.4-0.6\%. This $\mathrm{Ca}^{2+}$ may come from a small partial dissolution of the carbonates which are a part of both the binder and the aggregates.

No efflorescence has been found on the surface of of the studied materials. This does not prevent us from discarting the possibility of some salt sediments forming on the material surface. Nevertheless, according to the results obtained in this study, those sediments are found in a very small proportion.

In some stuccos the studies proved that there had been a loss of binding material, since the aggregates stood out and the binder was scarce. This phenomenon is accounted for by the fact that on the stucco surface a procees of partial solubilization can be produced by rain water) which sweeps away not only soluble salts but some lime and binder also. This accounts for the low proportion of water soluble salts as well.

Moreover, the coast of Cádiz is a geographical area with strong east winds that add to the separation of poorly united binder particles from vertical paraments due to physical and mechanical effects.

One of the phenomena observed in the Archaelogical Site of Baelo Claudia is the lost of adherenceof the stuccos with the support stone. The internal part of the stucco in contact with the stone is separated and is totally disintegrated. The support stone (calcarenite in many cases, limestone in others) is a highly porous material able to absorb a large amount of water. This 
poroso capaz de absorber una gran cantidad de agua. Este agua se mueve en el interior de la piedra, y en su movimiento intenta salir y evaporarse a través del recubrimiento estucado.

Los elevados valores de las porosidades accesibles al agua, de los estucos estudiados, están indicando que todos ellos presentan una elevada permeabilidad; sin embargo, se puede producir un estancamiento del agua líquida que puede favorecer la desintegración y solubilización parcial de la piedra calcárea, que conduce a los fenómenos de arenización descritos. Iniciado este proceso de deterioro, éste se puede acentuar por el desarrollo y crecimiento de microorganismos, en esa zona ya alterada, y que promuevan y provoquen la pérdida total de adherencia al alojarse en los huecos, fisuras o bolsas que se forman al separarse las distintas capas del estuco, y conduzcan a una disminución de su cohesión y consistencia.

El estudio realizado ha puesto en evidencia que una de las principales causas de deterioro de los estucos y hormigones estudiados es el ataque de tipo biológico, con la proliferación y colonización de distintos organismos en dichos materiales. Estas formaciones biológicas se han encontrado tanto en la superficie de los materiales como a diferentes profundidades, así como en las zonas interfaciales entre la piedra soporte y el estuco de cal. Se ha comprobado que en aquellas muestras, en las que no proliferaban estos microorganismos, su cohesión interna y adherencia era muy superior a la observada en materiales altamente atacados.

\section{AGRADECIMIENTOS}

Los autores quieren agradecer a la Consejería de Cultura de la Junta de Andalucía la subvención concedida para la realización de este trabajo. Agradecen igualmente, a la Dirección del Conjunto Arqueológico de Baelo Claudia las facilidades dadas para su consecución. También la hacen extensiva a la dedicación, observaciones y comentarios de $D^{a}$ Elisa Pinilla.

Así mismo, los autores agradecen al Dr. M. Hoyos, del Museo de Ciencias (C.S.I.C.), la preparación e intrepretación de las láminas delgadas presentadas en este estudio. moves inside the stone and while moving it tries to escape and evaporate through stuccoed coating.

The high values of water accessible porosities in the studied stuccos show that all of them have high permeability; nevertheless, this liquid water can become stagnant and thus favour the partial disintegration and solubilization of the calcareous stone, which leads to the described disintegration phenomena. When this process of decay begins it can be additionally intensified by the development and growth of microorganisms in the already altered area which enhance and provoke the total loss of bond since they inhabit holes, cracks and bags which form as the layers of stucco separate, leading to the decrease of its cohesion and consistence.

The study carried out has proved that one the main causes of decay of the stuccos and concretes studied is the biological-type attack with the proliferation and colonization of different organisms in these materials. These biological formations have been found on the surface of the different materials and at different depths as well as the interfacial areas between the support stone and lime stucco. It has been proved that those samples in which none of these microorganisms proliferated had a much better internal cohesion and bond than the strongly attacked materials.

\section{ACKNOWLEDGEMENTS}

The authors wish to thank the Conserjeria de Cultura of the Junta de Andalucia for the subsidy granted for the realization of this work. They also thank the Management of the Archaeological Site of Baelo Claudia for the facilities they provided for the execution of the work as well as Dr. Elisa Pinilla for her dedication, remarks and comments.

Finally, they would like thank Dr. M. Hoyos of the Museo de Ciencias (CSIC) for the preparation and intepretation of the thin sections presented in this study. 


\section{BIBLIOGRAFÍA}

(1) Borja, F.; Martínez, A; Troya, A. "El proceso histórico de destrucción de la ciudad romana de Baelo Claudia (SW Cádiz). Caracterización Geotécnica y análisis de formaciones superficiales. Seminario de Arqueología y Etnología Turolense. Colegio Universitario de Teruel. pp. 297-308 (1993)

(2) García Ramos, G.; Linares López, M $M^{\mathrm{a}}$ D.; Abad Casal, L. "Estudio fisicoquímico y mineralógico de algunas muestras de pinturas y revestimiento murales de Bolonia (Cádiz)”. Archivo Español de Arqueología. Vol 50-51 n 135-138 pp. 295-310 (1978)

(3) RILEM. Commission 25-PEM. "Protection et Erosion des Monumentes. Recommended tests to measure the deterioration of stone and the assess the effectiveness of treatment methods". Mat. Construct. 13, pp. 176-253 (1980)

\section{publicaciones del ICCET/CSIC}

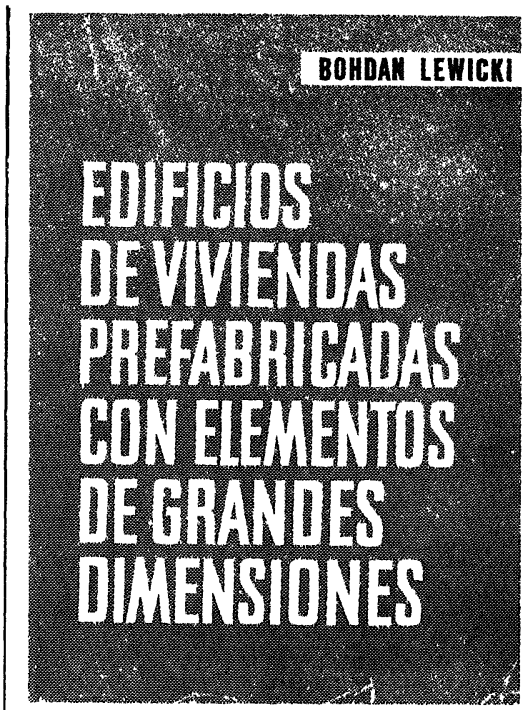

Bohdan Lewick

Este libro trata de los problemas relativos a la construcción de los edificios de viviendas - públicos realizados con elementos prefa. bricados de grandes dimensiones. Se han estudiado los problemas de arriostramiento, así como los que plantea la resistencia de los elementos y de la estructura; se han examinado las cuestiones de orden higrotérmico, acústico y de resistencia al fuego; también se ha profundizado en el estudio de la estanquidad de los muros exteriores y de las juntas.

La obra incluye numerosas ilustraciones que dan detalles de diversas soluciones, así como ejemplos de cálculo, tablas de valores numéricos, diagramas y ábacos.

Un volumen encuadernado en tela, de $24 \times 17 \mathrm{~cm}$, compuesto de 616 págs.

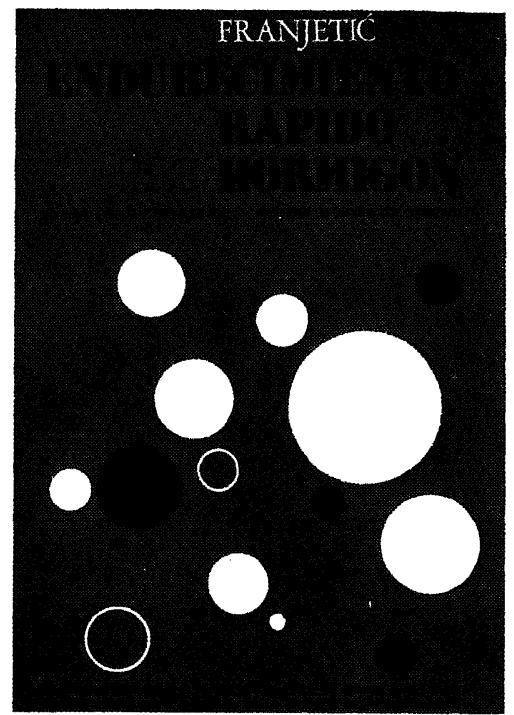

Zorislav Franjetic

En la obra de Franjetić se expone de una forma minuciosa, todo un cuerpo de doctrina que reúne el cotodo un cuerpo de doctrina que reune el conocimiento actual sobre el endurecimiento
rápido del hormigón. Parte el autor de los rápido del hormigón. Parte el autor de los
principios básicos y llega a las últimas consecuencias y realidades técnicas y económicas.

Es una obra de consulta, tanto para el in vestigador sobre la materia, como para el proyectista y el realizador y montador de plantas e instalaciones y equipos de curado y endurecimiento rápido.

Un volumen encuadernado en cartóné, de $17 \times 24,5 \mathrm{~cm}$, compuesto de 385 págs. 110 figuras y 10 tablas.

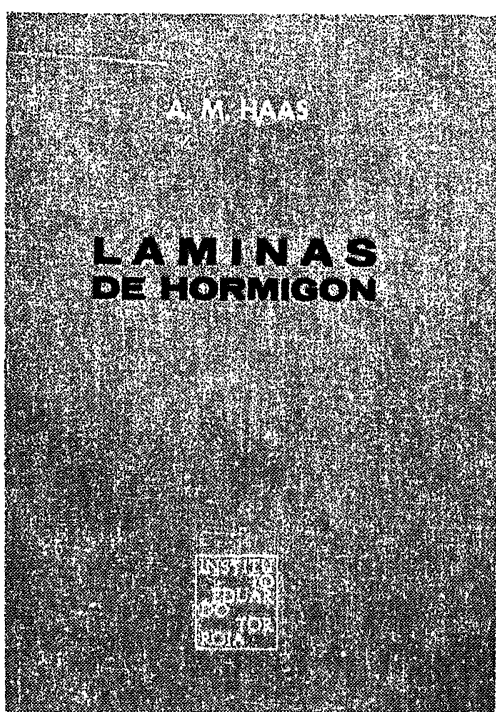

\section{A. M. Haas}

Al escribir este libro el autor intentó pone a disposición de los estudiantes y de los ingenieros unos conocimientos prácticos, adecuados para servir de guia en el diseño y construcción de láminas delgadas de hormigón.

El autor está convencido de que el éxito en el diseño de una lámina exige, por parte del proyectista, un examen de las tres fases por las que pasa la materialización de la lámina: el diseño, el análisis estructural y la construcción de la estructura.

In volumen encuadernado en tela, de $17 \times 24,5 \mathrm{~cm}$, compuesto de 420 págs., 141 figuras, 22 fotografias y 6 tablas. 